\title{
ERRATUM
}

\section{Bevacizumab and irinotecan therapy in glioblastoma multiforme: a series of 13 cases}

TO THE READERSHIP: An error appeared in the article by Ali et al. (Ali SA, McHayleh WM, Ahmad A, et al: Bevacizumab and irinotecan therapy in glioblastoma multiforme: a series of 13 cases. J Neurosurg 109:268-272, 2008).

The bevacizumab dosage was given as mg per square meter $\left(\mathrm{m}^{2}\right)$. The correct units are $\mathrm{mg}$ per kilogram $(\mathrm{kg})$ body weight $(\mathrm{mg} / \mathrm{kg})$.

The article has been corrected online as of November 24, 2017.

Gillian Shasby

Director of Publications Journal of Neurosurgery Publishing Group, Charlottesville, VA

INCLUDE WHEN CITING

Published online November 24, 2017; DOI: 10.3171/2017.8.JNS08268a.

CAANS 2018, except where prohibited by US copyright law 